\title{
Cereal gene bank accepts need for patents...
}

\section{Obregon, Mexico}

The world's leading maize and wheat research organization last week adopted an intellectual-property policy intended to ensure that its resources will remain available to scientists working for sustainable agriculture in developing nations.

The international board of trustees of the Mexico-based International Maize \& Wheat Improvement Centre (CIMMYT) — which holds the world's largest maize and wheat gene bank - unanimously approved the policy to prevent private companies from claiming intellectual-property rights over any of its discoveries or resources.

The centre fears its long-standing mission of providing germplasm free to plant breeders worldwide would be threatened without the policy. CIMMYT previously did not have a policy of protecting its research discoveries.

"Our desire is to ensure that inventions aren't patented out from under the organization," says Wallace Falcon, a Stanford University economist and CIMMYT board chairman.

CIMMYT board member Cary Fowler, a sociologist at the Agricultural Institute of Norway, cautioned that this is not an effort by the organization to "get rich" by patenting discoveries, but to ensure broad distribution of plant materials through a flexible policy.

Similar steps are being considered by other members of the Consultative Group on International Agricultural Research (CGIAR), an umbrella organization that supports sustainable agriculture for developing nations.

Last week, the Philippines-based International Rice Research Institute (IRRI) organized a conference in Los Baoos of the 12nation Council for Partnership on Rice Research (CORRA), where intellectual property and possible new laws in Asia for rice patenting were hot topics.

"These [intellectual property] legal requirements are new for many of us, but we have to study and introduce the necessary legislation as quickly as possible," says Joko Budianto, CORRA's chairman.

Research organizations that seek to further their intellectual-property rights were sharply criticized by groups such as the Spain-based Genetic Resources Action International (GRAIN).

"Pulling the rice cultures of Asia into the grips of corporate intellectual-property systems is not a win-win scenario," says GRAIN's director Henk Hobbelink. "Farmers will lose control over their production systems and biodiversity will suffer."

But CIMMYT trustee Fowler notes that research organizations have little choice in the rapidly evolving world of plant genomics. A year ago, he said, it would have been highly unlikely that the CIMMYT board would have

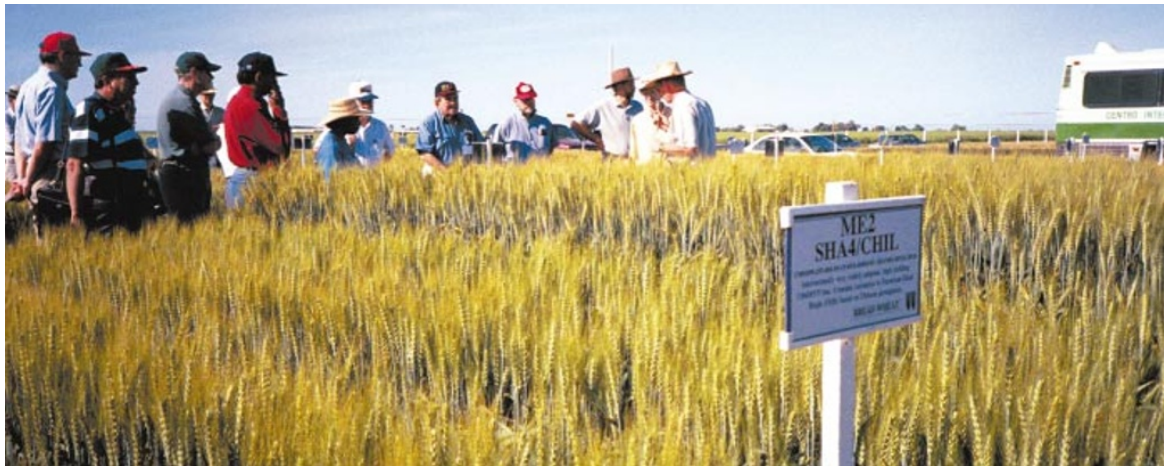

Crop protection: reforms will guarantee developing countries continued access to CIMMYT's seeds.

agreed to seek patent protection for its resources. But the centre fears private companies will exploit its openness and either patent a plant discovery or secure blocking patents that would limit its ability to improve crops.

As an example, the organization cites the case of a Colorado company that won US patent rights to a type of bean grown for years in Mexico and sold in California. The firm is suing in the US District Court to enforce its patent. Now the Mexican growers are alleging the patent is invalid.

Hope Shand, research director for the Canada-based Rural Advancement Foundation International, says these patent fights are exactly what organizations such as CIMMYT should avoid. "Filing patents and defending them is very expensive, taking scarce resources from agriculture research," she says.
Under a 1994 agreement, CIMMYT maintains designated germplasm in trust for the United Nation's Food and Agricultural Organization (FAO) in Rome. CIMMYT's intellectual-property policy is designed to adhere to that agreement to provide designated germplasm to the international community, officials said.

For discoveries associated with non-FAO designed germplasm, the CIMMYT policy calls for analysis on a case-by-case basis. The policy will cover patents, licensing agreements and/or partnerships.

Timothy Reeves, CIMMYT's director general, says: "The whole rationale behind the intellectual property policy is to keep discoveries available to CIMMYT" in order to continue its mission of disseminating science for sustainable agriculture. Rex Dalton

\section{... as Monsanto makes rice genome public}

Paris \& Sydney

The multinational life science company Monsanto this week announced the first complete sequencing of a crop plant genome - all 12 chromosomes of rice (Oryza sativa).

The company also promised that it would make the entire sequence available, with no strings attached, in the public domain, by donating it to the International Rice Genome Sequence Project (IRGSP), a Japanese-led consortium of ten publicly funded genome centres.

Takuji Sasaki, director of Japan's Rice Genome Research Program, the lead member of the consortium, told Nature that he applauded the Monsanto decision. He argued that the incorporation of Monsanto's database is an exemplary public-private sector collaboration, similar to the joint completion of the Drosophila genome by Celera Genomics and the publicly funded Drosophila Genome Project.

The rice genome, at $400 \mathrm{Mb}$, is some 37 times smaller than wheat, and six times smaller than maize. But identifying the position of genes in rice will help in finding similar genes in these crops. The public rice project, which was launched in 1998, is being led by Japan with $\$ 100$ million through its Rice Genome Research Program. Ten million dollars is also being contributed each by China, the United States and India.

The US effort is publicly funded through the Institute for Genomic Research. Monsanto says that its data will be sent to IRGSP, and "as each segment of the sequence is completed, it will be placed in the public domain in accordance with existing IRGSP policy."

The rice sequencing was carried out mainly by Leroy Hood at the University of Washington in Seattle, under contract for Monsanto. Sasaki says that the Monsanto sequence is of around $5 \mathrm{X}$ depth, and that many gaps remain. But merging the data with the $7 \mathrm{X}$ data from the public project should accelerate the completion of a 'finished' genome.

The IRGSP's initial target for completion was 2008 at a cost of $\$ 200$ million, but in a bid to shorten this Japan has increased its support for rice genomics three-fold, ironically in response to the threat that Celera and other companies might get their first (see Nature 401, 102; 1999). Declan Butler \& Peter Pockley 